\title{
ANALISIS PEMASARAN SUSU SEGAR SAPI PERAH DI KECAMATAN MOJOSONGO KABUPATEN BOYOLALI, JAWA TENGAH
}

\author{
MARKETING ANALYSIS ON FRESH MILK OF DAIRY COWS \\ IN MOJOSONGO SUB DISTRICT, BOYOLALI REGENCY
}

\author{
Sutrisno Hadi Purnomo*, Ayu Intan Sari, Muhammad Abdul Haris \\ Program Studi Peternakan, Fakultas Pertanian, Universitas Sebelas Maret, \\ Jl. Ir. Sutami 36A, Surakarta \\ *E-mail: sutrisnohadi@staff.uns.ac.id \\ (Diterima 18-1-2021; Disetujui 26-1-2021)
}

\begin{abstract}
ABSTRAK
Penelitian ini bertujuan menentukan jalur pemasaran paling efisien berdasarkan yang dilewati pedagang pengumpul untuk mendistribusikan susu segar dan menjaga kualitas susu segar dengan memilih rute terdekat, waktu tercepat dan efisiensi biaya. Selain itu, penelitian ini bertujuan untuk mengetahui biaya pemasaran, margin pemasaran, keuntungan dan efisiensi pemasaran yang dilaksanakan oleh lembaga pemasaran yang terlibat dalam sistem pemasaran susu segar. Penelitian ini dilaksanakan di Kecamatan Mojosongo, Kabupaten Boyolali, Jawa Tengah. Metode dasar penelitian ini adalah metode deskriptif dan pelaksanaannya menggunakan metode survei. Lokasi penelitian diambil secara purposive berdasarkan pertimbangan bahwa Kecamatan Mojosongo memiliki populasi sapi perah terbesar kedua di Kabupaten Boyolali. Metode analisis yang digunakan adalah analisis biaya pemasaran, margin pemasaran, keuntungan pemasaran, efisiensi pemasaran dan analisis Travelling Salesman Problem untuk menentukan jarak terdekat, waktu tercepat dan biaya terendah. Saluran Pemasaran Susu Segar Sapi Perah yang digunakan produsen di Kecamatan Mojosongo terdapat tiga saluran sebagai berikut Saluran I: Peternak ke Konsumen, Saluran II: Peternak ke Pedagang pengumpul ke Konsumen dan Saluran III: Peternak ke Pedagang pengumpul ke Pedagang besar ke Industri pengolahan susu. Saluran I merupakan saluran pemasaran yang paling efisien karena pada saluran ini peternak menjual langsung ke konsumen. Jalur pemasaran paling efisien dengan menggunakan metode Travelling Salesman Problem adalah jalur distribusi II karena pada jalur ini memiliki jarak terdekat, waktu tercepat untuk menjaga kualitas susu segar serta efisiensi biaya.
\end{abstract}

Kata Kunci: Susu segar sapi perah, Saluran pemasaran, Biaya, Margin, Efisiensi pemasaran

\section{ABSTRACT}

This study aims to determine the most efficient marketing channel based on what collectors pass through to distribute fresh milk and maintain the quality of fresh milk by choosing the closest route, the fastest time and cost efficiency. In addition, this study aims to determine marketing costs, marketing margins, profits and marketing efficiency carried out by marketing agencies involved in the fresh milk marketing system. This research was conducted in Mojosongo District, Boyolali Regency, Central Java. This research was conducted in Mojosongo District, Boyolali Regency, Central Java. The basic method of this research is descriptive method and its implementation uses a survey method. The research location was taken purposively based on the consideration that Mojosongo District has the second largest dairy cow population in Boyolali Regency. The analysis method used is the analysis of marketing costs, marketing margins, marketing profits, marketing efficiency and the Traveling Salesman Problem analysis to determine the closest distance, fastest time and lowest cost. There are three channels for the Marketing of Fresh Milk for Dairy Cows used by producers in Mojosongo District as follows: Channel I: Farmers to Consumers, Channel II: Farmers to Traders, Collectors to Consumers and Channel III: Farmers to Traders, collectors to Wholesalers to the milk processing industry Channel I is the most efficient marketing channel 
because in this channel breeders sell directly to consumers. The most efficient marketing channel using the Traveling Salesman Problem method is distribution line II because this route has the closest distance, the fastest time to maintain the quality of fresh milk and cost efficiency.

Keywords: fresh milk for dairy cows, marketing channels, costs, margins, marketing efficiency

\section{PENDAHULUAN}

$$
\text { Sapi perah umumnya }
$$
dibudidayakan di dataran tinggi yang berudara dingin, hal ini dikarenakan produksi susu yang baik berada di daerah dataran tinggi dengan suhu $5-21^{\circ} \mathrm{C}$. Meningkatnya kebutuhan susu sapi memacu peningkatan produksi susu sapi di Kabupaten Boyolali. Hal tersebut ditunjukkan pada tahun 2017 produksi susu sebanyak 46.775.509 liter sedangkan pada tahun 2018 meningkat menjadi 48.075.220 liter. Kecamatan Mojosongo merupakan salah satu kecamatan yang memiliki produksi susu sapi cukup tinggi di Kabupaten Boyolali. Produksi susu sapi di Kecamatan Mojosongo pada tahun 2012 sebanyak 6.644.402 liter dan mengalami kenaikan pada tahun 2018 sebanyak 6.744 .302 liter (Badan Pusat Statistik Kabupaten Boyolali, 2018).

Permasalahan yang sering dihadapi dalam pemasaran susu segar adalah kualitas susu segar yang cepat menurun. Susu yang baru saja diperah akan mengalami perubahan kualitas apabila tidak segera ditangani. Saluran pemasaran yang baik berguna untuk mengatasi permasalahan kualitas susu segar yang cepat menurun (Sari et al, 2017). Saluran pemasaran menurut segi waktu dan biaya sebagian besar belum jelas tingkat efisiensinya, seperti halnya saluran pemasaran susu segar di Kecamatan Mojosongo Kabupaten Boyolali. Oleh karena itu, peneliti melakukan penelitian yang bertujuan menentukan jalur pemasaran paling efisien berdasarkan yang dilewati pedagang pengumpul untuk mendistribusikan susu segar dan menjaga kualitas susu segar dengan memilih rute terdekat, waktu tercepat dan efisiensi biaya.

\section{METODE PENELITIAN}

Penelitian ini dilaksanakan di Kecamatan Mojosongo, Kabupaten Boyolali, Jawa Tengah. Metode dasar yang digunakan dalam penelitian ini adalah metode survey, yaitu penelitian dengan menggunakan pertanyaan terstruktur atau sistematis yang sama kepada banyak orang. Penelitian ini menggunakan metode pengambilan 
sampel peternak secara sengaja (purposive sampling) pada sampel produsen yaitu dipilih sebanyak 60 responden dari 968 peternak sapi perah. Pengambilan sampel ini berdasarkan desa yang memiliki populasi sapi perah tertinggi di Kecamatan Mojosongo yaitu berada di Desa Singosari. Data yang diperoleh dalam penelitian ini terdiri atas data primer yaitu data yang dikumpulkan langsung oleh peneliti dari para responden, dan bukan berasal dari pengumpulan data yang pernah dilakukan sebelumnya; dan data sekunder yaitu data-data pendukung yang diperoleh dari buku-buku, maupun sumber lain yang diterbitkan oleh instansi terkait. Teknik pengumpulan data yang digunakan dalam penelitian ini yaitu wawancara, observasi, pencatatan dan studi pustaka.

Analisis data yang digunakan dalam penelitian ini adalah analisis biaya pemasaran, analisis margin pemasaran, analisis keuntungan pemasaran, efisiensi pemasaran dan analisis Traveling Salesman Problem (TSP) susu segar sapi perah di Kecamatan Mojosongo.

\section{HASIL DAN PEMBAHASAN}

Penelitian ini dilaksanakan di Kabupaten Boyolali tepatnya di Kecamatan Mojosongo yang memiliki potensi untuk dikembangkan menjadi daerah basis usaha ternak sapi perah dengan pertimbangan letak dan kondisi geografis yang sesuai. Kecamatan Mojosongo terletak pada ketinggian 100$400 \mathrm{~m}$ di atas permukaan laut dengan iklim tropis yaitu memiliki suhu $25-27^{\circ} \mathrm{C}$, mempunyai kemiringan tanah $<15 \%$, kondisi tanah datar, $\mathrm{pH}$ tanah 6-7 dan jenis tanahnya regasol. Luas wilayah kecamatan ini yaitu 2163,69 Ha dengan jumlah penduduk pada tahun 2017 sebanyak 4369 jiwa (Badan Pusat Statistik Kabupaten Boyolali, 2018). Ternak sapi perah di Kecamatan Mojosongo sebanyak 15.247 ekor dan merupakan ternak ruminansia paling banyak dibudidayakan. Desa yang memiliki populasi ternak sapi perah terbanyak adalah Desa Singosari sedangkan populasi yang terendah berada di Desa Dlingo (BP3K Kecamatan Mojosongo, 2017).

Potensi sektor peternakan sapi perah di Kecamatan Mojosongo merupakan aset penting yang perlu dikembangkan secara terarah, terpadu dan berkesinambungan serta diharapkan dapat menunjang kelanjutan pembangunan dalam kapasitasnya sebagai sumber protein hewani yang kaya gizi sebagai sumber pendapatan. Jenis 
ternak ruminansia yang paling banyak dibudidayakan sebagai usaha peternakan oleh masyarakat Kecamatan Mojosongo adalah ternak sapi perah yaitu sebanyak 15.247 ekor.

Pemasaran susu segar sapi perah di Kecamatan Mojosongo memiliki beberapa kendala pemasaran seperti kualitas susu yang cepat menurun, lama pengiriman, dan mahalnya biaya transportasi sehingga diperlukan saluran pemasaran yang cepat, efisien, dan tidak memakan waktu yang lama. Saluran pemasaran yang baik berguna untuk mengatasi permasalahan kualitas susu segar yang cepat menurun. Saluran pemasaran menurut segi waktu dan biaya sebagian besar belum jelas tingkat efisiensinya, seperti halnya saluran pemasaran susu segar di Kecamatan Mojosongo Kabupaten Boyolali.

\section{Profil Responden Peternak}

Umur peternak berpengaruh dalam usaha ternak sapi perah. Peternak yang berumur produktif adalah umur antara 15 tahun sampai 64 tahun (Arsyad, 1999). Berdasarkan Tabel 1 diperoleh jumlah dan presentase responden dengan ratarata usia peternak sapi perah di Kecamatan Mojosongo tergolong usia produktif yaitu pada interval umur 15 sampai 64 tahun yaitu sebanyak 55 peternak atau $91,7 \%$.

Tabel 1. Profil responden peternak sapi perah

\begin{tabular}{|c|c|c|c|}
\hline \multirow[b]{2}{*}{ No } & \multirow[b]{2}{*}{ Uraian } & \multicolumn{2}{|c|}{ Jumlah Responden } \\
\hline & & $\begin{array}{c}\text { Peternak } \\
\text { (orang) }\end{array}$ & $\begin{array}{c}\text { Persentase } \\
(\%)\end{array}$ \\
\hline \multirow[t]{4}{*}{1} & Umur (Tahun) & & \\
\hline & a. $0-15$ & - & _ \\
\hline & b. $16-64$ & 55 & 91,7 \\
\hline & c. $>64$ & 5 & 8,3 \\
\hline \multirow[t]{5}{*}{2} & Pendidikan & & \\
\hline & a. $\mathrm{SD} / \mathrm{MI}$ & 38 & 63,3 \\
\hline & b. SLTP & 6 & 10,1 \\
\hline & c. SLTA & 14 & 23,3 \\
\hline & d. D3/ Sarjana & 2 & 3,3 \\
\hline \multirow[t]{6}{*}{3} & \multicolumn{3}{|c|}{ Pengalaman Usaha (Tahun) } \\
\hline & a. $\quad<10$ & 10 & 16,7 \\
\hline & b. $10-19$ & 26 & 43,3 \\
\hline & c. $20-29$ & 13 & 21,7 \\
\hline & d. $>29$ & 11 & 18,3 \\
\hline & Total & 60 & 100 \\
\hline
\end{tabular}

Tingkat pendidikan peternak yang paling banyak yaitu SD sebanyak 38 responden atau 63,3\%. Tingkat pendidikan peternak sapi perah di Kecamatan Mojosongo relatif masih rendah dikarenakan masyarakat terkendala ekonomi. Hal ini membuat peternak kurang tertarik melanjutkan pendidikan yang lebih tinggi, selain itu tingkat kesadaran akan pentingnya pendidikan masih kurang. Semakin tinggi pendidikan maka akan memperoleh halhal baru sehingga bisa diimplementasikan dengan usaha ternak yang berkembang.

Pengalaman beternak rata-rata responden mayoritas 10-19 tahun yaitu sebesar 43,3\%. Menurut pendapat 
Priyanto (2008), pengalaman usaha ternak cukup mendukung pengembangan skala usaha sebab semakin meningkat pengalaman usaha ternak ada kecenderungan peternak memutuskan untuk memperbesar skala usaha.

\section{Profil Lembaga Pemasaran}

Pada kegiatan pendistribusian barang, terdapat pedagang perantara atau disebut juga sebagai lembaga pemasaran. Lembaga pemasaran mempunyai peran penting dalam kegiatan pemasaran susu segar sehingga distribusi susu segar menjadi lancar. Lembaga pemasaran adalah badan usaha atau individu yang menyelenggarakan pemasaran, menyalurkan jasa dan komoditi dari produsen kepada konsumen akhir, serta mempunyai hubungan dengan badan usaha atau individu lain (Sudiyono, 2002).

Menurut Tabel 2 dapat diketahui umur responden pedagang pengumpul tergolong dalam umur produktif yaitu antara 16-64 tahun. Responden pedagang pengumpul mempunyai pengalaman usaha yang cukup lama, hal ini dapat menjadi pendukung dalam kegiatan pemasaran dikarenakan responden pedagang pengumpul dapat memperoleh informasi pasar dan pengetahuan teknologi.

Tabel 2. Profil pelaku lembaga pemasaran susu segar

\begin{tabular}{|c|c|c|c|}
\hline \multirow[b]{2}{*}{ No } & \multirow[b]{2}{*}{ Uraian } & \multicolumn{2}{|c|}{ Jumlah Responden } \\
\hline & & $\begin{array}{c}\text { Pedagang } \\
\text { (orang) }\end{array}$ & $\begin{array}{c}\text { Persentase } \\
(\%)\end{array}$ \\
\hline \multirow[t]{4}{*}{1} & Umur (Tahun) & & \\
\hline & a. $0-15$ & - & - \\
\hline & b. $16-64$ & 4 & 100 \\
\hline & c. $>64$ & - & - \\
\hline \multirow[t]{5}{*}{2} & Pendidikan & & \\
\hline & a. $\mathrm{SD} / \mathrm{MI}$ & 2 & 50 \\
\hline & b. SLTP & - & - \\
\hline & c. SLTA & 1 & 25 \\
\hline & d. Diploma/Sarjana & 1 & 25 \\
\hline \multirow[t]{6}{*}{3} & Pengalaman Usaha & ahun) & \\
\hline & a. $<10$ & - & - \\
\hline & b. $10-19$ & - & - \\
\hline & c. $20-29$ & 2 & 50 \\
\hline & d. $>29$ & 2 & 50 \\
\hline & Total & 4 & 100 \\
\hline
\end{tabular}

Tingkat pendidikan responden lembaga pemasaran mayoritas yaitu SMA sebanyak 2 orang, SD 1 orang dan setingkat sarjana 1 orang responden. Pada usaha penjualan susu segar diperlukan keahlian khusus untuk kegiatan pemasaran. Keahlian khusus diperoleh dari pelatihan yang diberikan kepada pedagang pengumpul seperti melakukan uji massa jenis, uji rasa, uji bau dan uji warna.

\section{Tugas dan Fungsi Lembaga}

\section{Pemasaran}

Lembaga pemasaran dalam memasarkan susu segar mempunyai beberapa fungsi dan tugas seperti fungsi 
pertukaran, fungsi fisik dan fungsi fasilitas (Sartika dan Hellyward, 2017).
Fungsi-fungsi tersebut dapat dilihat pada Tabel 3.

Tabel 3. Fungsi-fungsi Pemasaran

\begin{tabular}{lcccc}
\hline Fungsi-fungsi pemasaran & Peternak & $\begin{array}{c}\text { Pedagang } \\
\text { Pengumpul }\end{array}$ & $\begin{array}{c}\text { Pedagang } \\
\text { Besar }\end{array}$ & $\begin{array}{c}\text { Industri } \\
\text { Pengolahan Susu }\end{array}$ \\
\hline Pertukaran & & & & $\checkmark$ \\
a. Pembelian & $\checkmark$ & $\checkmark$ & $\checkmark$ & $\checkmark$ \\
b. Penjualan & $\checkmark$ & $\checkmark$ & $\checkmark$ & $\checkmark$ \\
\hline Fisik & & $\checkmark$ & $\checkmark$ & $\checkmark$ \\
a. Penampungan & $\checkmark$ & $\checkmark$ & $\checkmark$ \\
b. Pengangkutan & & & $\checkmark$ \\
c. Grading & & $\checkmark$ & $\checkmark$ \\
d. Pengemasan & & & \\
e. Penyimpanan & & $\checkmark$ & $\checkmark$ \\
Fasilitas & & $\checkmark$ & $\checkmark$ \\
a. Penanggungan resiko & & $\checkmark$ & $\checkmark$ \\
b. Pembiayaan & & $\checkmark$ & & \\
c. Penyampaian informasi pasar & $\checkmark$ & & & \\
\hline Sumber: Data primer terolah, 2018 & &
\end{tabular}

Berdasarkan Tabel 3 dapat disimpulkan bahwa tugas dan fungsi lembaga pemasaran di Kecamatan Mojosongo meliputi fungsi pertukaran, fisik dan fasilitas. Hal ini ketiga fungsi tersebut dilakukan oleh semua lembaga pemasaran baik pedagang pengumpul, pedagang besar maupun industri pengolahan susu. Fungsi pertukaran meliputi pembelian dan penjualan. Fungsi fisik meliputi penampungan, pengangkutan, grading, pengemasan dan penyimpanan. Fungsi fisik terjadi pada saat adanya penambahan kegunaan waktu, tempat dan bentuk pada produk ketika produk diangkut, disimpan dan diproses untuk memenuhi keinginan konsumen. Fungsi fasilitas dilakukan oleh lembaga pemasaran yang meliputi penanggungan resiko, pembiayaan dan penyampaian informasi. Lembaga pemasaran sudah memenuhi ketiga aspek fungsi fasilitas dengan baik.

\section{Saluran Pemasaran Susu Segar Sapi Perah di Kecamatan Mojosongo}

Peternak sapi perah menjual susu segar melalui 3 saluran pemasaran. Saluran pemasaran tersebut adalah:

(1) Peternak $\rightarrow$ Konsumen

(2) Peternak $\rightarrow$ Pedagang pengumpul $\rightarrow$ Konsumen

(3) Peternak $\rightarrow$ Pedagang pengumpul $\rightarrow$ Pedagang besar $\rightarrow$ Industri pengolahan susu 
Tabel 4. Jumlah peternak pada masing-masing saluran pemasaran

\begin{tabular}{cccc}
\multicolumn{4}{c}{ saluran pemasaran } \\
No & $\begin{array}{c}\text { Saluran } \\
\text { pemasaran }\end{array}$ & $\begin{array}{c}\text { Jumlah } \\
\text { Peternak } \\
\text { (Orang) }\end{array}$ & $\begin{array}{c}\text { Presentase } \\
(\%)\end{array}$ \\
\hline 1 & I & 8 & 13,3 \\
2 & II & 22 & 36,7 \\
3 & III & 30 & 50 \\
\hline & Jumlah & 60 & 100 \\
\hline
\end{tabular}

Sumber: Data primer terolah, 2018

Tabel 4 menunjukkan bahwa saluran yang paling banyak digunakan oleh peternak susu segar sapi perah di Kecamatan Mojosongo adalah saluran III yaitu sebanyak 30 peternak atau 50\%. Pada saluran III pedagang pengumpul melakukan kegiatan pemasaran dengan membeli susu segar sapi perah dari konsumen, selanjutnya susu segar sapi perah dibeli oleh pedagang besar untuk dijual kepada industri pengolahan susu. Pada Saluran pemasaran II dan III peternak lebih condong untuk menjual susu segar kepada pedagang pengumpul sehingga dalam pemasaran lebih mudah dan efisien karena jumlah yang banyak dan kualitas susu segar cepat menurun.

Biaya Pemasaran, Margin, Keuntungan dan Farmer's Share pada Pemasaran Susu Segar Sapi Perah di Kecamatan Mojosongo

Besarnya biaya pemasaran susu segar sapi perah pada saluran pemasaran I dapat dilihat pada Tabel 5.
Tabel 5. Rata-rata biaya pemasaran susu segar pada saluran pemasaran I

\begin{tabular}{clr}
\hline No & \multicolumn{1}{c}{ Uraian biaya } & Rp/liter $/ \mathrm{hr}$ \\
\hline 1 & Harga jual susu segar & 4.800 \\
& oleh peternak & \\
2 & Harga beli konsumen & 4.800 \\
3 & Farmer's share & $100 \%$ \\
\hline
\end{tabular}

Sumber: Data primer terolah, 2018

Berdasarkan Tabel 5 pola saluran pemasaran susu segar yang pertama paling efisien karena mempunyai nilai farmer's share tinggi yaitu $100 \%$. Semakin panjang saluran pemasaran yang digunakan, maka biaya pemasaran yang dikeluarkan akan semakin tinggi (Estiyati, 2010). Rata-rata biaya pemasaran susu segar pada saluran pemasaran II dapat dilihat pada Tabel 6 .

Tabel 6. Rata-rata biaya pemasaran susu segar sapi perah pada saluran pemasaran II

\begin{tabular}{cll}
\hline No & Uraian biaya & $\begin{array}{c}\text { Rp/liter/ } \\
\text { hari }\end{array}$ \\
\hline 1. & $\begin{array}{l}\text { Harga jual susu segar oleh } \\
\text { peternak }\end{array}$ & 4.400 \\
\hline 2. & $\begin{array}{l}\text { Pedagang pengumpul } \\
\text { a. Harga beli }\end{array}$ & \\
& b. Biaya pemasaran & 4.400 \\
& • Transportasi & 54 \\
• Bongkar Muat & 56 \\
$\quad$ c. Harga jual & 110 \\
& $\begin{array}{l}\text { d. Margin pemasaran } \\
\text { e. Keuntungan }\end{array}$ & 4.800 \\
f. Farmer's Share & 290 \\
\hline
\end{tabular}

Sumber: Data primer terolah, 2018

Berdasarkan Tabel 6 hanya terdapat 1 lembaga pemasaran yang terlibat yaitu pedagang pengumpul. Tabel di atas dapat disimpulkan harga yang diterima peternak sebesar $\mathrm{Rp}$ 4.400,00, pada 
pemasaran ini tidak ada biaya pemasaran yang dikeluarkan oleh peternak. Harga yang diperoleh pedagang pengumpul yang kemudian dijual ke konsumen sebesar Rp 4.800,00. Cara konsumen untuk membeli susu segar dilakukan dengan mendatangi rumah pedagang pengumpul. Besar biaya pengangkutan transportasi yang dikeluarkan dalam biaya pemasaran sebesar $\mathrm{Rp} 54,00 /$ liter yang diperoleh dari rata-rata biaya transportasi dibagi rata-rata jumlah liter susu yang dijual dan biaya bongkar muat $\mathrm{Rp} 56,00 /$ liter yang diperoleh dari ratarata biaya bongkar muat dibagi rata-rata jumlah liter susu yang dijual. Sedangkan total keuntungan Rp 290,00/liter. Total margin pemasaran adalah Rp 400,00/liter dan Farmer's share sebesar 91,6\%. Ratarata biaya pemasaran susu segar setiap lembaga pemasaran pada saluran pemasaran III dapat dilihat pada Tabel 7.

Berdasarkan hasil analisis biaya pemasaran, saluran I mengeluarkan biaya terendah yaitu Rp 0,00 sedangkan biaya pemasaran tertinggi terdapat pada saluran III yaitu Rp 476,00 dan biaya pemasaran pada saluran II sebesar Rp 110,00. Saluran pemasaran II dan III pada dasarnya sama, tetapi pada saluran II pedagang pengumpul memasarkan susu segar ke konsumen langsung sedangkan pada saluran III kegiatan pemasaran di salurkan ke pedagang besar kemudian ke industri pengolahan susu. Berdasarkan hal ini, dapat disimpulkan bahwa saluran I merupakan saluran yang paling efektif karena tidak mengeluarkan biaya pemasaran sama sekali.

Tabel 7. Rata-rata biaya pemasaran susu segar sapi perah pada saluran pemasaran III

\begin{tabular}{|c|c|c|}
\hline No & Uraian biaya & $\begin{array}{l}\text { Rp/liter } \\
\text { / hari }\end{array}$ \\
\hline 1 & $\begin{array}{l}\text { Harga jual susu segar oleh } \\
\text { peternak }\end{array}$ & 4.400 \\
\hline \multirow[t]{10}{*}{2} & Pedagang pengumpul & \\
\hline & Harga beli & 4.400 \\
\hline & Biaya pemasaran & \\
\hline & Transportasi & 54 \\
\hline & Bongkar Muat & 56 \\
\hline & Retribusi pasar & 125 \\
\hline & Jumlah biaya & 235 \\
\hline & Harga jual & 4.800 \\
\hline & Margin pemasaran & 400 \\
\hline & Keuntungan & 165 \\
\hline \multirow[t]{10}{*}{3} & Pedagang Besar & \\
\hline & Harga beli & 4.800 \\
\hline & Biaya pemasaran & \\
\hline & Transportasi & 61 \\
\hline & Bongkar Muat & 55 \\
\hline & Retribusi pasar & 125 \\
\hline & Jumlah biaya & 241 \\
\hline & Harga jual & 5.200 \\
\hline & Margin pemasaran & 400 \\
\hline & Keuntungan & 159 \\
\hline \multirow[t]{4}{*}{4} & Total biaya pemasaran & 476 \\
\hline & Total margin pemasaran & 800 \\
\hline & Total keuntungan & 324 \\
\hline & Farmer Share & $84,6 \%$ \\
\hline
\end{tabular}

Keuntungan pemasaran susu segar di Kecamatan Mojosongo pada setiap lembaga pemasaran berbeda-beda. Hal ini dikarenakan setiap lembaga pemasaran menetapkan harga yang tidak sama. Keuntungan pemasaran yang terbesar 
terdapat pada saluran III yaitu Rp 324,00 karena memiliki lembaga pemasaran yang paling banyak. Saluran I memiliki keuntungan pemasaran terendah yaitu $\mathrm{Rp}$ 0,00 karena pada saluran I tidak ada lembaga pemasaran yang terlibat dan keuntungan pemasaran pada saluran II sebesar Rp 290,00 .

Margin pemasaran diperoleh dari selisih harga beli konsumen dengan harga yang diterima peternak. Besarnya margin pemasaran setiap lembaga pemasaran dipengaruhi oleh biaya dan keuntungan pemasaran yang diambil oleh setiap lembaga pemasaran. Saluran pemasaran yang memiliki nilai margin pemasaran tertinggi adalah saluran III yaitu $\mathrm{Rp}$ 800,00 sedangkan margin pemasaran terendah terdapat pada saluran I yaitu $\mathrm{Rp}$
0,00 dan saluran pemasaran II memiliki margin pemasaran sebesar Rp 400,00. Saluran III memiliki tingkat efisiensi terendah karena memiliki nilai margin pemasaran paling tinggi dibandingkan dengan ketiga saluran lainnya. Widitantono (2012) menyatakan bahwa semakin rendah margin pemasaran, semakin tinggi bagian yang diterima petani (farmer's share) dan semakin pendek saluran pemasaran maka pemasaran semakin efisien.

\section{Efisiensi Pemasaran Susu Segar Sapi} Perah di Kecamatan Mojosongo

Perbandingan total biaya, keuntungan, margin pemasaran dan Farmer's share dapat dilihat pada Tabel 8.

Tabel 8. Perbandingan total biaya, keuntungan, dan total margin pemasaran pada setiap saluran pemasaran susu segar sapi perah

\begin{tabular}{clcccc}
\hline No & $\begin{array}{c}\text { Saluran } \\
\text { pemasaran }\end{array}$ & $\begin{array}{c}\text { Total biaya } \\
(\mathrm{Rp} / \text { liter/hr) }\end{array}$ & $\begin{array}{c}\text { Total keuntungan } \\
(\mathrm{Rp} / \text { liter/hr })\end{array}$ & $\begin{array}{c}\text { Total margin } \\
\text { pemasaran } \\
(\mathrm{Rp} / \text { liter/hr })\end{array}$ & $\begin{array}{c}\text { Farmer's share } \\
(\%)\end{array}$ \\
\hline 1. & Saluran I & - & - & - & 100 \\
2. & Saluran II & 110 & 290 & 400 & 91,6 \\
3. & Saluran III & 476 & 324 & 800 & 84,6
\end{tabular}

Sumber: Data primer terolah, 2018

Efisiensi pemasaran secara ekonomi dapat diketahui dari besarnya bagian yang diterima produsen (farmer's share). Pemasaran susu segar dianggap efisien secara ekonomis apabila pada saluran pemasarannya bagian yang diterima peternak (farmer's share) mempunyai nilai tinggi. Abadi (2007) menyatakan bahwa pemasaran dikatakan efisien apabila bagian yang diterima produsen $>50 \%$ dan bila bagian yang diterima produsen $\quad<50 \%$ berarti pemasaran belum efisien. 
Travelling Salesman Problem (TSP) Susu Segar

Analisis data pada penelitian pemasaran susu segar sapi perah di Kecamatan Mojosongo menggunakan Travelling Salesman Problem (TSP) dengan menentukan jarak, waktu dan biaya minimum. Perbandingan jarak tempuh, waktu perjalanan dan biaya distribusi susu segar sapi perah di Kecamatan Mojosongo dapat dilihat pada Tabel 9.

Tabel 9. Jarak tempuh, waktu perjalanan, dan biaya distribusi susu segar sapi perah

\begin{tabular}{cccccc}
\hline \multirow{2}{*}{ Jalur } & \multicolumn{2}{c}{ Jarak Tempuh $(\mathrm{Km})$} & \multicolumn{2}{c}{ Waktu Perjalanan } & Biaya (Rp) \\
\cline { 2 - 6 } & Pagi & Sore & Pagi & Sore & \\
\hline 1 & 15,5 & 15,5 & $42^{\prime} 10^{\prime \prime}: 53$ & $43^{\prime} 13^{\prime \prime}: 26$ & 50.000 \\
\hline 2 & 22,3 & 22,8 & $47^{\prime} 47^{\prime \prime}: 56$ & $41^{\prime} 35^{\prime \prime}: 15$ & 62.500 \\
\hline 3 & 23,7 & - & $57^{\prime} 16^{\prime \prime}: 20$ & - & 25.000 \\
\hline
\end{tabular}

Sumber: Data primer terolah, 2018

Rute pemasaran susu dari pedagang pengumpul ke industri pengolahan susu sebagai berikut:

Jalur 1 : Pengumpul $\rightarrow$ (Pos 1-8) $\quad \rightarrow$ KUD Kota Boyolali

Jalur 2: Pengumpul $\rightarrow$ (Pos 1-12) $\rightarrow$ Koperasi Andini Luhur Jalur 3 : Pengumpul $\rightarrow($ Pos 1-4) $\quad \rightarrow$ KSU Keju Boyolali

Pendistribusian susu segar yang dilakukan pedagang pengumpul Bapak Pramono dilakukan oleh supir sudah cukup baik dengan jalur yang ditentukan. Penelitian ini menerapkan metode Travelling Salesman Problem (TSP) dalam penentuan jalur distribusi susu segar. Adapun rute distribusi susu segar menggunakan metode Travelling Salesman Problem, yaitu:

Jalur 1: Pedagang pengumpul Bapak Pramono $\sim$ Pos $1 \sim$ Pos $2 \sim$ Pos
3 Pos $4 \sim \operatorname{Pos} 5 \sim \operatorname{Pos} 6 \sim \operatorname{Pos}$ $7 \sim$ Pos $8 \sim$ KUD Kota Boyolali. Total jarak yang ditempuh 31 $\mathrm{km}$, total waktu distribusi selama 85,24 menit dan total biaya $\mathrm{Rp}$ $50.000,00$.

Jalur 2: Pedagang pengumpul Bapak Pramono $\sim$ Pos $1 \sim$ Pos $2 \sim$ Pos 3 Pos $4 \sim$ Pos $5 \sim$ Pos $6 \sim$ Pos $7 \sim \operatorname{Pos} 8 \sim \operatorname{Pos} 9 \sim \operatorname{Pos} 10 \sim \operatorname{Pos}$ $11 \sim$ Pos $12 \sim$ Koperasi Andini Luhur. Total jarak yang ditempuh $50,1 \mathrm{~km}$, total waktu distribusi selama 88,83 menit dan total biaya $\operatorname{Rp} 62.500,00$.

Jalur 3: Pedagang pengumpul Bapak Pramono $\sim$ Pos $1 \sim$ Pos $2 \sim$ Pos 3 Pos $4 \sim$ KSU Keju Boyolali. Total jarak yang ditempuh 23,7 $\mathrm{km}$, total waktu distribusi selama 
Tabel 10. Rata-rata jarak tempuh, waktu perjalanan, dan biaya distribusi susu segar sapi perah di Kecamatan Mojosongo

\begin{tabular}{|c|c|c|c|c|c|c|}
\hline \multirow[t]{2}{*}{ Jalur } & \multirow[t]{2}{*}{ Jumlah Pos } & \multicolumn{2}{|c|}{ Jarak Tempuh /Pos (Km) } & \multicolumn{2}{|c|}{ Waktu Perjalanan/Pos } & \multirow[t]{2}{*}{ Biaya /Pos(Rp } \\
\hline & & Pagi & Sore & Pagi & Sore & \\
\hline 1 & 8 & 1,9 & 1,9 & $5,15^{\prime \prime}: 53$ & $5^{\prime} 20^{\prime \prime}: 26$ & 6.250 \\
\hline 2 & 12 & 1,8 & 1,8 & 3' 54": 60 & 3' 15": 15 & 5.200 \\
\hline 3 & 4 & 5,9 & - & $14^{\prime} 15^{\prime \prime}: 20$ & - & 6.250 \\
\hline
\end{tabular}

Menurut Tabel 10 jalur pemasaran paling efisiensi adalah jalur 2 karena pada jalur ini jarak tempuh yaitu 1,8 $\mathrm{km} /$ pos, waktu perjalanan yaitu 3,35 menit/pos, dan biaya distribusi sebesar Rp 5.200,00/pos. Travelling Salesman Problem (TSP) yang terdapat pada jalur pemasaran 2 dinilai lebih efisien dengan rata-rata jarak terpendek, waktu tercepat dan biaya terendah karena pada jalur ini memiliki 12 pos yang harus dilewati. Saluran pemasaran II dan III yang melalui pedagang pengumpul lebih efektif dan efisien menggunakan jalur 2 karena pada jalur ini membutuhkan jarak, waktu dan biaya terendah.

\section{KESIMPULAN DAN SARAN}

\section{Kesimpulan}

Berdasarkan hasil penelitian yang telah dilakukan, saluran pemasaran susu segar sapi perah di Kecamatan Mojosongo Kabupaten Boyolali didapatkan kesimpulan:
1. Saluran Pemasaran Susu Segar Sapi Perah yang digunakan produsen di Kecamatan Mojosongo terdapat tiga saluran sebagai berikut Saluran I: Peternak $\rightarrow$ Konsumen, Saluran II: Peternak $\rightarrow$ Pedagang pengumpul $\rightarrow$ Konsumen dan Saluran III: Peternak $\rightarrow$ Pedagang pengumpul $\rightarrow$ Pedagang besar $\rightarrow$ Industri pengolahan susu.

2. Pola saluran pemasaran susu segar sapi perah di Kecamatan Mojosongo yang banyak digunakan oleh peternak adalah saluran III sebanyak 30 responden atau 50\% dari responden karena peternak lebih menekankan kemudahan dalam proses penjualan, efisiensi waktu penjualan dan kepercayaan kepada pedagang pengumpul.

3. Saluran I merupakan saluran pemasaran yang paling efisien karena pada saluran ini biaya pemasaran yaitu $\mathrm{Rp} \quad 0,00$ dan peternak memperoleh nilai efisiensi tertinggi sebesar $100 \%$. 
4. Jalur pemasaran paling efisien adalah jalur 2 karena pada jalur ini memiliki jarak terdekat, waktu tercepat untuk menjaga kualitas susu segar serta efisiensi biaya.

\section{Saran}

Beberapa saran yang dapat direkomendasikan kepada peternak sapi perah sebagai berikut:

1. Peternak sebaiknya memilih saluran pemasaran langsung, yaitu saluran pemasaran I. Pada saluran pemasaran I peternak tidak menggunakan lembaga pemasaran, sehingga saluran tersebut lebih efisien dan menguntungkan.

2. Pedagang pengumpul dalam menentukan saluran pemasaran perlu memperhatikan biaya pemasaran yang dikeluarkan sehingga pedagang pengumpul sebaiknya memilih saluran pemasaran II. Pada saluran pemasaran tersebut, pedagang pengumpul tidak perlu keluar kota dalam mendistribusikan susunya.

3. Pedagang pengumpul perlu menjaga kualitas susu segar yang mudah menurun, maka jalur pemasaran yang dipilih adalah jalur pemasaran II. Pada jalur ini pedagang pengumpul lebih efisiensi dan dapat memperoleh keuntungan yang lebih besar.

\section{DAFTAR PUSTAKA}

Abadi, F. N. 2007. Analisis Pemasaran Keripik Tempe di Kecamatan Sambungmacan Kabupaten Sragen. Program Studi Agribisnis Fakultas Pertanian Universitas Sebelas Maret Surakarta, Surakarta.

Arsyad, L. 1999. Ekonomi Pembangunan Edisi keempat. Universitas Gadjah Mada, Yogyakarta.

Badan Penyuluh Pertanian Perikanan dan Kehutanan. 2015. Kecamatan Mojosongo dalam Angka. Kecamatan Mojosongo, Boyolali

Badan Pusat Statistik Kabupaten Boyolali. 2018. Kabupaten Boyolali dalam Angka. Kabupaten Boyolali, Boyolali.

Estiyati, I. 2010. Analisis Pemasaran Belimbing Manis (Aveerhoa Carambola L.) di Kabupaten Jepara. Program Studi Agribisnis Fakultas Pertanian Universitas Sebelas Maret, Surakarta.

Fidiena A., K. Prasetyowati, Suswadi. 2017. Strategi Pemasaran Susu Sapi Perah Di KUD Musuk Kabupaten Boyolali. Jurnal Ilmiah Agrineca. Vol. 20 No. 1

Priyanto, D. 2008. Target Kelayakan Skala Usaha ternak Domba Pola Pembibitan Mendukung Pendapatan Peternak Di Perdesaan. Pusat Analisis Sosial Ekonomi Dan Kebijakan Pertanian. Departemen pertanian. Balai Penelitian Ternak Bogor, Bogor.

Sari A.I., S.H. Purnomo, S. Emawati, E.T. Rahayu, B.S. Hertanto, M. A. Haris. 2017. Efisiensi Pemasaran Melalui Minimasi Jalur Distribusi Susu Segar Sapi Perah Di Kecamatan Mojosongo Kabupaten 
Boyolali. Caraka Tani: Journal of Sustainable Agriculture. Vol. 32 No 1

Sartika, W dan J. Hellyward. 2017.

Bauran Pemasaran Susu Sapi dan

Susu Kambing Segar di Kota Padang. Jurnal Peternakan Indonesia. Vol. 19 No. 3
Sudiyono, A. 2002. Pemasaran Pertanian. Universitas Muhammadiyah Malang Press, Malang.

Widitantono, A. 2012. Analisis Pemasaran Ternak Sapi Potong di Kecamatan Playen Kabupaten Gunung Kidul. Skripsi. Program Studi Peternakan, Fakultas Pertanian, Universitas Sebelas Maret, 